DOE/NASA/2593-16

NASA TM-81520

\title{
EVALUATION OF HOT CORROSION BEHAVIOR OF THERMAL BARRIER COATINGS
}

P.E. Hodge, R.A. Miller, and M.A. Gedwill

National Aeronautics and Space Administration

Lewis Research Center

Work performed for

U.S. DEPARTMENT OF ENERGY

Energy Technology

Fossil Fuel Utilization Division

Prepared for

International Conference on Metallurgical Coatings

sponsored by American Vacuum Society

San Diego, California, April 21-25, 1980 


\section{NOTICE}

This report was prepared to document work sponsored by the United States Government. Neither the United States nor its agent, the United States Department of Energy, nor any Federal employees, nor any of their contractors, subcontractors or their employees, makes any warranty, express or implied, or assumes any legal liability or responsibility for the accuracy, completeness, or usefulness of any information, apparatus, product or process disclosed, or represents that its use would not infringe privately owned rights. 
DOE/NASA/2593-16

NASA TM-81520

\section{EVALUATION OF HOT CORROSION BEHAVIOR OF THERMAL BARRIER COATINGS}

P.E. Hodge, R.A. Miller, and M.A. Gedwill

National Aeronautics and Space Administration

Lewis Research Center

Cleveland, Ohio 44135

Performed for

U.S. DEPARTMENT OF ENERGY

Energy Technology

Fossil Fuel Utilization

Washington, D.C. 20545

Under Interagency Agreement EF-77-A-01-2593

International Conference on Metallurgical Coatings sponsored by American Vacuum Society

San Diego, California, April 21-25, 1980 

EVALUATION OF HOT CORROSION BEHAVIOR OF THERMAL BARRIER COATINGS

\author{
by P. E. Hodge, R. A. Miller, and M. A. Gedwill \\ National Aeronautics and Space Administration \\ Lewis Research Center \\ Cleveland, Ohio 44135
}

\title{
INTRODUCTION
}

Currently, there is considerable interest in the use of insulating ceramic thermal barrier coatings (TBCs) on cooled hot section components of gas turbines. These coatings are presently being developed for both clean-fuel aircraft gas turbines and the anticipated dirty-fuel environments of industrial/ utility gas turbines. Such insulative coatings can give temperature drops of $100^{\circ}$ to $200^{\circ} \mathrm{C}$ when only $0.04 \mathrm{~cm}$ thick. This large temperature drop offers substantial potential gains in heat engine efficiency by permitting higher gas temperatures with no change in component temperature or in durability by lowering metal temperature. The basis for the current interest in ceramic TBCs was brought about by the good performance of such coatings in clean fuel combustion gas exposures (refs. 1 to 3 ). However, early results with the $\mathrm{ZrO}_{2}-12 \mathrm{Y}_{2} \mathrm{O}_{3} / \mathrm{NiCrA1Y}$ system in the presence of the usual heavy fuel impurities $(\mathrm{Na}, \mathrm{V}$, etc.) were less than encouraging (ref. 4). In burner rig tests at NASA Lewis, two coatings systems, $\mathrm{ZrO}_{2}-8 \mathrm{Y}_{2} \mathrm{O}_{3}$ and a calcium silicate TBC, were identified as having substantially more resistance to spalling in Na plus $V$ doped combustion gases than previously tested systems (ref. 5). A number of TBCs based on calcium silicate, on improved $\mathrm{ZrO}_{2}-\mathrm{Y}_{2} \mathrm{O}_{3}$ compositions, and on improved $\mathrm{NiCrAlY}$ and CoCrAlY bond coats were evaluated recently in similar burner rig hot corrosion tests. The purpose of this paper is to present and discuss these results.

\section{EXPERIMENTAL PROCEDURE}

Materials and plasma spray coating deposition. - The chemical compositions and specifications for $1.8 \mathrm{CaO} \mathrm{SiO}_{2}$ and $\mathrm{ZrO}_{2}-\mathrm{Y}_{2} \mathrm{O}_{3}$ plasma spray powders and cast nickel-base alloy IN-79 2 hollow erosion bar substrates have been documented previously (refs. 3 and 5). All plasma spray bond coats were analyzed and found to have trace impurity levels comparable to the levels in bond coats used in reference 3. Both thermal barrier and bond coatings were applied manually in an open-air environment with a subsonic plasma spray gun using argon as the plasma gas. Metallographically measured coating thicknesses varied locally from 0.005 to $0.018 \mathrm{~cm}$ for a nominal $0.013 \mathrm{~cm}$ thick coating, and by about $\pm 0.010 \mathrm{~cm}$ for all thicker coatings. The zirconia coatings were about 88 percent dense with interconnected porosity while calcium silicate coatings were more dense and had fewer interconnected pores.

Cyclic Mach 0.3 burner rig tests. - The Mach 0.3 burner rig used in these studies is described in reference 5. Briefly, air, fuel, and an aqueous solution of $\mathrm{NaOH}$ and $\mathrm{NH}_{4} \mathrm{VO}_{3}$ were injected into the combustor, ignited, and expanded through a nozzle at a velocity of Mach 0.3. The dopant levels of $\mathrm{Na}$ and $\mathrm{V}$ in the combustion gases were adjusted to correspond to a fuel equivalent of $5 \mathrm{ppm}$ $\mathrm{Na}$ and $2 \mathrm{ppm} \mathrm{V}$. Cooling air flow was calibrated to maintain the metal sub- 
strate at $843^{\circ} \mathrm{C}$ for $0.038 \mathrm{~cm} \mathrm{ZrO}_{2}-8 \mathrm{Y}_{2} \mathrm{O}_{3}$ coated specimens. Test parameters based on the calibration runs were: fuel/air mass ratio of 0.046 , calculated adiabatic flame temperature of $1552^{\circ} \mathrm{C}$, coating surface temperature of $982^{\circ} \mathrm{C}$, metal substrate temperature of $843^{\circ} \mathrm{C}$, specimen holder rotation of $450 \mathrm{rpm}$, and specimen distance from the nozzle of $3.2 \mathrm{~cm}$.

Coated specimens were exposed to thermal cycles consisting of 1 hour at temperature followed by 6 minutes of external forced air cooling to below $100^{\circ} \mathrm{C}$. Internal cooling air was maintained constant during both heating and cooling cycles. Specimens were inspected after each twenty 1-hour cycles. Specimens were removed when the ceramic had spalled over approximately onefourth of the hot zone on the leading edge. Coating lives reported represented the average removal time of two specimens, but individual variations in life generally were no more than \pm 15 percent from that average. A representative number of exposed specimens were selected for metallographic (all specimens polished in varasol to retain water soluble condensates), XRD, SEM, EMP, and chemical analyses to determine the extent of hot corrosion and to identify condensates and the mode of spalling.

\section{RESULTS AND DISCUSSION}

Test results. - The response of the TBCs to the Na plus $\mathrm{V}$ doped Mach 0.3 combustion gases is summarized in figure 1. In general the data show (1) that the durability of TBC systems may be substantially improved by reducing the thickness of the TBC from 0.038 to $0.013 \mathrm{~cm}$, (2) that high $\mathrm{Cr}+\mathrm{Al}$ bond coatings improve the durability of $\mathrm{TBC}$ systems, (3) that $1.8 \mathrm{CaO} \mathrm{SiO}_{2}$ coatings are more durable than $\mathrm{ZrO}_{2}-8 \mathrm{Y}_{2} \mathrm{O}_{3}$ at comparable ceramic thicknesses with the same bond coatings, and (4) that $\mathrm{ZrO}_{2}-12 \mathrm{Y}_{2} \mathrm{O}_{3}$ and $\mathrm{ZrO}_{2}-6 \mathrm{Y}_{2} \mathrm{O}_{3} \mathrm{TBCs}$ are less durable than $\mathrm{ZrO}_{2}-8 \mathrm{Y}_{2} \mathrm{O}_{3} \mathrm{TBCs}$ when evaluated with the same baseline bond coating. Specimens with $0.013 \mathrm{~cm}$ thick ceramic coatings have higher bond coat and lower ceramic surface temperatures compared to specimens with $0.038 \mathrm{~cm}$ thick ceramic coatings. If the temperatures within the ceramic coating or at the bond coat/ceramic interface are higher than the dew points of the condensates (e.g., $905^{\circ} \mathrm{C}$ for $\mathrm{Na}_{2} \mathrm{SO}_{4}$ ) no condensation can occur at this location which may account for the increased durability of TBC systems with thinner ceramic coatings. No apparent hot corrosion of the bond coatings was evident from metallographic examination of the tested specimens. The improved durability of TBC systems with various bond coatings thus may not be due to differences in bond coat hot corrosion resistance.

Analyses of test specimens. - Two modes of spalling of the TBCs were observed for specimens exposed in these hot corrosion tests. $1.8 \mathrm{CaO} \mathrm{SiO}_{2}$ coated specimens spalled in the center of the hot zone. In a few cases, as with YSZ coated specimens, they failed at the upper edge of the hot zone as illustrated in figure 2. Points $A, B$, and $C$ in figure 2 show where crosssections were taken for metallographic and EMP analyses and points $D, E$, and $F$ show where samples were taken for SEM/EDAX, chemical, and XRD analyses.

The post-test analyses of some representative specimens are summarized in table I. X-ray data for 6 and 8 w/o YSZ indicated no gross changes in the tetragonal to monoclinic ratio. XRD of exposed calcium silicate coated specimens showed the following: (1) There was a phase change of $\mathrm{B}_{-\mathrm{Ca}_{2} \mathrm{SiO}}$ (1arnite) to $\mathrm{CaSiO}_{3}$ (wollastonite). Further testing is needed to determine if this 
phase change was reaction or thermally induced. (2) $\mathrm{CaSO}_{4}$ was formed in both hot and relatively cold areas of $1.8 \mathrm{CaO}^{\mathrm{SiO}} 2$ test specimens, probably by a gas-phase reaction with $\mathrm{SO}_{2}$. Calcium sulfate has also been observed in similar tests at Westinghouse ( $R$. J. Bratton, private communication) and calcium silicate/ $\mathrm{SO}_{2}$ reactions have been reported in reference 6 . SEM/EDAX and chemical analyses show that $\mathrm{Na}, \mathrm{S}$, and $\mathrm{V}$ are present at the surface or within exposed $\mathrm{YSZ}$ and $1.8 \mathrm{CaO}^{\mathrm{SiO}} 2$ coatings. These are probably the reaction and condensation products of $\mathrm{Na}_{2} \mathrm{SO}_{4}, \mathrm{Na}_{2} \mathrm{~V}_{2} \mathrm{O}_{6}$, and $\mathrm{V}_{2} \mathrm{O}_{5} . \mathrm{Co}, \mathrm{Fe}, W$, and $\mathrm{Ni}$, found only in $1.8 \mathrm{CaO} \mathrm{SiO}_{2}$ coatings, probably evolved from the L-605 Co-based Mach 0.3 burner rig nozzle.

The results of EMP mapping studies of exposed $\mathrm{ZrO}_{2}-8 \mathrm{Y}_{2} \mathrm{O}_{3}$ and calcium silicate coated specimens were in general agreement with the XRD, chemical and SEM/EDAX analyses. In figure $3(\mathrm{a})$ there is good correspondence between $\mathrm{Na}$ and $\mathrm{S}$ in a $\mathrm{ZrO}_{2}-8 \mathrm{Y}_{2} \mathrm{O}_{3}$ coated specimen and this is taken as evidence that $\mathrm{Na}_{2} \mathrm{SO}_{4}$ formed in the flame and condensed in coating pores and cracks. The scans of $V$ (not shown) and $Y$ indicated local concentrations of $Y$ and some correspondence with $V$ in some of these areas (probably $\mathrm{YVO}_{4}$ ). Additional EMP scans on the same specimen at the colder $A$ and $C$ sections show some correspondence between $\mathrm{Na}, \mathrm{S}$, and $\mathrm{Y}$ and between $\mathrm{S}$ and $\mathrm{Y}$ which is believed to be the possible forma$t$ ion of $\mathrm{Y}_{2}\left(\mathrm{SO}_{4}\right)_{3}$ or $\mathrm{Y}_{2} \mathrm{~S}_{3}$. EMP scans of $\mathrm{Ca}, \mathrm{Si}, \mathrm{S}, \mathrm{Na}, \mathrm{V}, \mathrm{r}_{\mathrm{O}}$, and $\mathrm{W}$ in a typical calcium silicate specimen at the A section show several interesting features (fig. 3(b)). This specimen had spalled in the hot zone as indicated in figure 2. There is almost a $1: 1$ correspondence of $\mathrm{Na}$ and $\mathrm{S}$ indicating $\mathrm{Na}_{2} \mathrm{SO}_{4}$ formation and some $\mathrm{V}$ and $\mathrm{Na}$ overlap at the surface which is probably $\mathrm{Na}_{2} \mathrm{~V}_{2} \mathrm{O}_{6}$. of the elements evolving from the L-605 nozzle, only co penetrated calcium silicate to any extent. Additional $S$ in the interior of the coating is taken as an indication of $\mathrm{CaSO}_{4}$ formation below the surface. EMP scans of the $B$ section of the same specimen in the hotter spalled area show $\mathrm{S}\left(\mathrm{CaSO}_{4}\right.$ from $\mathrm{SO}_{2}$ reaction with $1.8 \mathrm{CaO}^{\mathrm{SiO}_{2}}$ ) and very little if any $\mathrm{Na}$ within the entire 0.005 to $0.013 \mathrm{~cm}$ remaining coating. However, the bulk of the coating was still calcium silicate based on the EMP scans of $\mathrm{Si}, \mathrm{Ca}$, and XRD results.

Calculation of dew points of potential condensates. - Based on calculations similar to those in reference 7 and the temperatures shown in figure 1, either $\mathrm{V}_{2} \mathrm{O}_{5}$ (1) (dew point $1210^{\circ} \mathrm{C}$ ) or $\mathrm{Na}_{2} \mathrm{~V}_{2} \mathrm{O}_{6}$ (1) (dew point $1155^{\circ} \mathrm{C}$ ) should condense and penetrate the zirconia coatings over the entire specimen length. $\mathrm{Na}_{2} \mathrm{SO}_{4}$ (1) (dew point, $905^{\circ} \mathrm{C}$ ) should only condense outside the hot zone and penetrate only to a limited extent. Spallation of YSZ coated specimens occurred at the edge of the hot zone which implies that $\mathrm{Na}_{2} \mathrm{SO}_{4}$ (1) played a key role in causing failure of these coatings. Coating spallation may be caused by solidification of salt in the pores and microcracks of the coating which results in compressive stresses because the microcracks cannot fully close upon further cooling. EMP analyses show $\mathrm{Na}_{2} \mathrm{SO}_{4}$ within the $\mathrm{ZrO}_{2}-8 \mathrm{Y}_{2} \mathrm{O}_{3}$ coating which tends to support this argument. On the other hand EMP data also showed that reactions occurred between some $\mathrm{Y}-\mathrm{rich}$ areas and $\mathrm{S}-$ and $\mathrm{V}$-containing condensates. This could destabilize $\mathrm{ZrO}_{2}-\mathrm{Y}_{2} \mathrm{O}_{3}$ and cause in spallation due to the thermal expansion difference between tetragonal and additional monoclinic zirconia.

The spalling behavior of calcium silicate is complicated. Most calcium silicate coated specimens spalled in the hot zone. Failure in the hot zone is believed to be due to a gas-phase temperature-dependent reaction of $\mathrm{SO}_{2}$ with calcium silicate to form $\mathrm{CaSO}_{4}$. Based on EMP data, spallation of a few cal- 
cium silicate coatings at the edge of the hot zone appears to be due to penetration of $\mathrm{Na}_{2} \mathrm{SO}_{4}, \mathrm{Na}_{2} \mathrm{~V}_{2} \mathrm{O}_{6}$, and Co containing condensates. Further exposure studies followed by analyses will be needed to clarify the mechanism of calcium silicate coating spallation and determine how the phase change of $\mathrm{B}-\mathrm{Ca}_{2} \mathrm{SiO}_{4}$ (larnite) to $\mathrm{CaSiO}_{3}$ (wollastonite) affects this mechanism.

\section{SUMMARY OF RESULTS}

The lives of $1.8 \mathrm{CaO} \mathrm{SiO} 2$ and $\mathrm{ZrO}_{2}-8 \mathrm{Y}_{2} \mathrm{O}_{3}$ thermal barrier coatings exposed to Mach $0.3 \mathrm{Na}$ plus $\mathrm{V}$ doped combustion gases were about four times longer when the ceramic thickness was reduced from 0.038 to $0.013 \mathrm{~cm}$. High $\mathrm{Cr}+\mathrm{Al}$, $\mathrm{Ni}-31 \mathrm{Cr}-11, \mathrm{~A} 1-.5 \mathrm{Y}$ and $\mathrm{Ni}-16 \mathrm{Cr}-13 \mathrm{Al}-.4 \mathrm{Y}$ bond coatings improved the durability of calcium silicate and $\mathrm{ZrO}_{2}-8 \mathrm{Y}_{2} \mathrm{O}_{3} \mathrm{TBCs}$ by approximately $2 \mathrm{X}$ to $3 \mathrm{X}$. Similarly, Co-22Cr-13A1-0.3Y and Co-20Cr-9Al-. $4 Y$ bond coatings improved the durability of calcium silicate TBCs approximately $3 \mathrm{X}$ and $2 \mathrm{X}$, respectively. Chemical and electron microprobe analyses supported the predictions of condensate compositions and their role in inducing spalling of $\mathrm{ZrO}_{2}-8 \mathrm{Y}_{2} \mathrm{O}_{3}$. Calcium silicate coating failure involved condensation and penetration of $\mathrm{Na}, \mathrm{V}$, and Co containing condensates, $\mathrm{CaSO}_{4}$ formation as a result of reaction with $\mathrm{SO}_{2}$, and the phase change from $\mathrm{B}_{-}-\mathrm{Ca}_{2} \mathrm{SiO}_{4}$ (larnite) to $\mathrm{CaSiO}_{3}$ (wollastonite).

\section{REFERENCES}

1. S. Stecura, NASA TM-X 3425, 1976.

2. S. Stecura, NASA TM-78976, 1978.

3. S. Stecura, NASA TM-79206, 1979.

4. R. J. Bratton, S. C. Singhal, and S. Y. Lee, EPRI RP-421-1, Electric Power Research Institute, 1979.

5. P. E. Hode, S. Stecura, M. A. Gedwill, I. Zaplatynsky, and S. R. Levine, NASA TM-79005, 1978.

6. M. Shen and A. S. Albanese, BNL-50992, Briikhaven National Laboratory, 1979 .

7. R. A. Miller, NASA TM-79 205, 1979. 
TABLE I. - PRE- AND POST-TEST ANALYSES

\begin{tabular}{|c|c|c|c|c|c|c|}
\hline \multirow{2}{*}{$\begin{array}{c}\text { Coating system* } \\
\text { test time }\end{array}$} & \multirow{2}{*}{$\begin{array}{l}\text { Location } \\
\text { of } \\
\text { analyses** }\end{array}$} & \multicolumn{2}{|c|}{ XRDA } & \multicolumn{2}{|c|}{ Chemical analyses } & \multirow{2}{*}{$\begin{array}{l}\text { Impurities } \\
\text { detected } \\
\text { by SEM/EDAX }\end{array}$} \\
\hline & & Pre-test & Post-test & $\begin{array}{l}\text { Atomic } \\
\text { absorp- } \\
\text { tion }\end{array}$ & $\begin{array}{l}\text { X-ray } \\
\text { fluores- } \\
\text { ence }\end{array}$ & \\
\hline $\begin{array}{l}\mathrm{ZrO}_{2}-8 \mathrm{Y}_{2} \mathrm{O}_{3} \mathrm{l} \\
\mathrm{Ni}-16 \mathrm{Cr}-6 \mathrm{~A} 1-.31 \mathrm{Y} \\
1201 \text {-hour cycles }\end{array}$ & $\begin{array}{l}\mathrm{D} \\
\mathrm{E}\end{array}$ & $\begin{array}{c}\text { Tetragonal(s), Monoclinic(w) } \\
"\end{array}$ & $\begin{array}{c}\text { Same } \\
"\end{array}$ & $\begin{array}{l}\mathrm{Na}{ }^{\mathrm{b}} \\
\mathrm{Na}\end{array}$ & $\begin{array}{l}\mathrm{S} \\
\mathrm{S}\end{array}$ & $\begin{array}{l}\mathrm{V}, \mathrm{Ni} \\
\mathrm{V}\end{array}$ \\
\hline $\begin{array}{l}\mathrm{ZrO}_{2}-6 \mathrm{Y}_{2} \mathrm{O}_{3} / \\
\mathrm{Ni}-16 \mathrm{Cr}-6 \mathrm{Al}-.31 \mathrm{Y} \\
801 \text {-hour cycles }\end{array}$ & $\begin{array}{l}\mathrm{D} \\
\mathrm{E}\end{array}$ & $\begin{array}{c}\text { Tegragonal (s), Monoclinic(w) } \\
\text { " }\end{array}$ & $\begin{array}{l}\text { Same } \\
"\end{array}$ & $\begin{array}{l}\mathrm{Na}{ }^{\mathrm{b}} \\
\mathrm{Na}\end{array}$ & $\mathrm{s}$ & $\begin{array}{l}v^{c} \\
v^{c}\end{array}$ \\
\hline $\begin{array}{l}1.8 \mathrm{CaO} \cdot \mathrm{SiO}_{2} \text { ' } \\
\mathrm{Co}-22 \mathrm{Cr}-13 \mathrm{Al}-.3 \mathrm{Y} \\
6201 \text {-hour cycles }\end{array}$ & $\begin{array}{l}\mathrm{D} \\
\mathrm{E} \\
\mathrm{F} \\
\mathrm{FF}^{\mathrm{a}}\end{array}$ & $\begin{array}{cc}\mathrm{BCa}_{2} \mathrm{SiO}_{4}(\mathrm{~s}) & \text { Larnite } \\
" & " \\
" & "\end{array}$ & $\begin{array}{l}\mathrm{CaSiO}_{3} \text { Wollastonite(s), } \mathrm{CeO}_{2}(\mathrm{w}) \\
\mathrm{CaSiO}_{3}, \mathrm{CeO}_{2}(\mathrm{w}), \mathrm{CaWO}_{4}(\mathrm{w}) \\
\mathrm{CaSO}_{4}(\mathrm{~s}), \mathrm{CaWO}_{4}(\mathrm{~s}), \mathrm{CaSiO}_{3}(\mathrm{w})\end{array}$ & $\begin{array}{l}\mathrm{Na} \\
\mathrm{Na} \\
\mathrm{Na}^{\mathrm{b}}\end{array}$ & $\begin{array}{l}\mathrm{s} \\
\mathrm{s} \\
\mathrm{s}\end{array}$ & $\begin{array}{l}\mathrm{Na}, \mathrm{S}, \mathrm{Co}, \mathrm{W}, \mathrm{Ni}, \mathrm{Ce} \\
\mathrm{v}, \mathrm{S}, \mathrm{Co}, \mathrm{Ni}, \mathrm{W}, \mathrm{Ce} \\
\mathrm{v}, \mathrm{S}, \mathrm{Co}, \mathrm{Ni}, \mathrm{Fe}, \mathrm{Ce} \\
\mathrm{s}, \mathrm{Ce}\end{array}$ \\
\hline $\begin{array}{l}1.8 \mathrm{CaO} \cdot \mathrm{SiO}_{2} / \\
\mathrm{Ni}-16 \mathrm{Cr}-6 \mathrm{Al}-.31 \mathrm{Y} \\
1601 \text {-hour cycles }\end{array}$ & $\begin{array}{l}\mathrm{D} \\
\mathrm{E} \\
\mathrm{F} \\
\mathrm{DD}^{\mathrm{a}}\end{array}$ & $\mid \begin{array}{cc}\mathrm{BCa}_{2} \mathrm{SiO}_{4}(\mathrm{~s}) & \text { Larnite } \\
" & "\end{array}$ & $\begin{array}{l}\mathrm{CaSiO}_{3}(\mathrm{~s}), \mathrm{NiO}-\mathrm{CoO}(\mathrm{s}) \\
\mathrm{CaSO}_{4}(\mathrm{w}), \mathrm{CaSiO}_{3}(\mathrm{~m}), \mathrm{CeO}_{2}(\mathrm{~s}) \\
\mathrm{CaSO}_{4}(\mathrm{~s}), \mathrm{CeO}_{2}(\mathrm{~s}), \mathrm{CaSiO}_{3}(\mathrm{w})\end{array}$ & $\begin{array}{l}\mathrm{Na} \\
\mathrm{Na} \\
\mathrm{Na}\end{array}$ & $\begin{array}{l}\mathrm{s} \\
\mathrm{s} \\
\mathrm{s}\end{array}$ & $\begin{array}{l}\mathrm{Na}, \mathrm{S}, \mathrm{V}, \mathrm{Co}, \mathrm{Fe}, \mathrm{Ni}, \mathrm{Ce} \\
\mathrm{S}, \mathrm{V}, \mathrm{Fe}, \mathrm{Ni}, \mathrm{Ce} \\
\mathrm{S}, \mathrm{V}, \mathrm{Co}, \mathrm{Fe}, \mathrm{Ni}, \mathrm{Ce} \\
\mathrm{S}, \mathrm{Ce}\end{array}$ \\
\hline
\end{tabular}

${ }^{*} 0.038 \mathrm{~cm}$ thick ceramic coatings for coating systems listed.

${ }^{* *}$ Calcium silicate coated specimens with failure patterns of left-hand specimen in figure 2.

${ }^{a}$ Sample taken at approximate depth of $0.020 \mathrm{~cm}$ compared to all other samples taken 0 to $0.013 \mathrm{~cm}$ from surface.

b Approximately twice the background amount of Na. $S$ was present in these samples.

${ }^{c}$ Just discernible above background. 


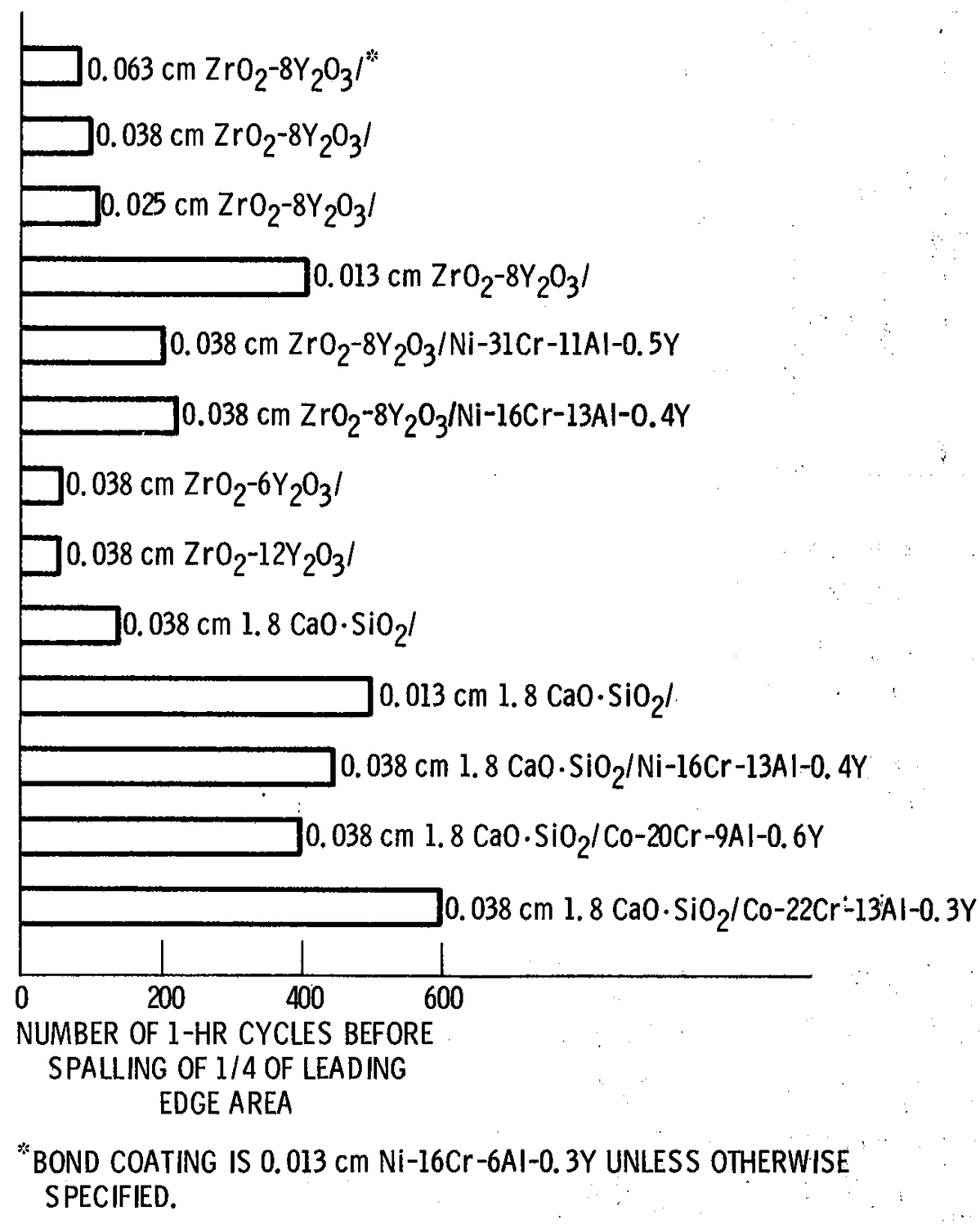

Figure 1. - Mach 0.3 burner rig corrosion test: fuel impurity level, $5 \mathrm{ppm} \mathrm{Na}+2 \mathrm{ppm} \mathrm{V}$; fuel/air $=0.046$; ceramic surface temperature, $982^{\circ} \mathrm{C}$; substrate temperature, $843^{\circ} \mathrm{C}$. 


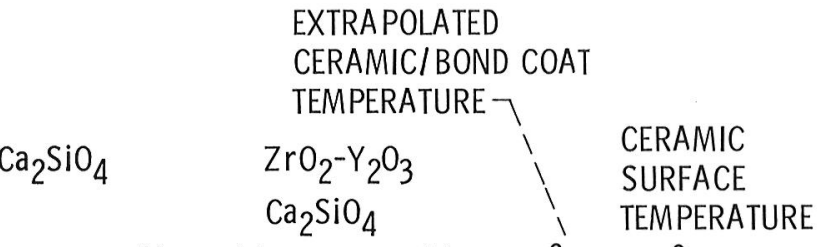

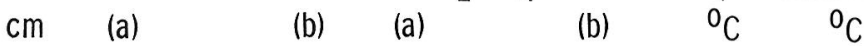

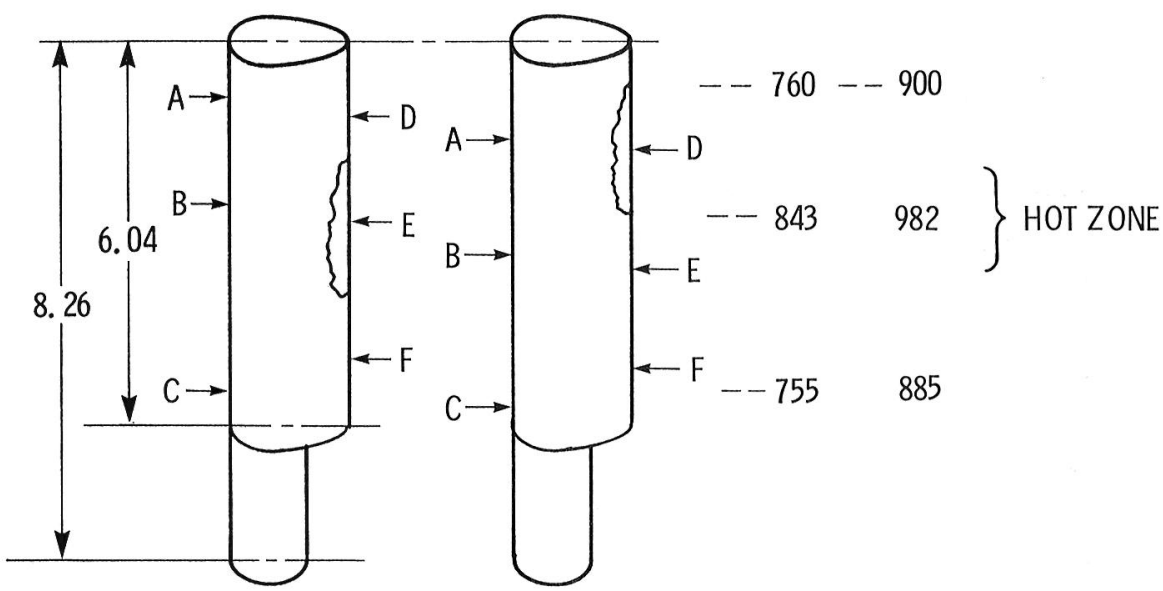

a A, B, AND C DENOTE LOCATIONS OF CROSS- SECTIONS FOR METALLOGRAPHY AND ELECTRON MICROPROBE SPECIMENS

b D, E, AND $F$ DENOTE LOCATIONS WHERE SAMPLES WERE TAKEN FOR XRD, CHEMICAL AND SEM/EDAX ANALYSES

Figure 2. - Typical failure pattern of thermal barrier coatings after exposure to Mach 0. 3 Na plus $V$ doped combustion gases.
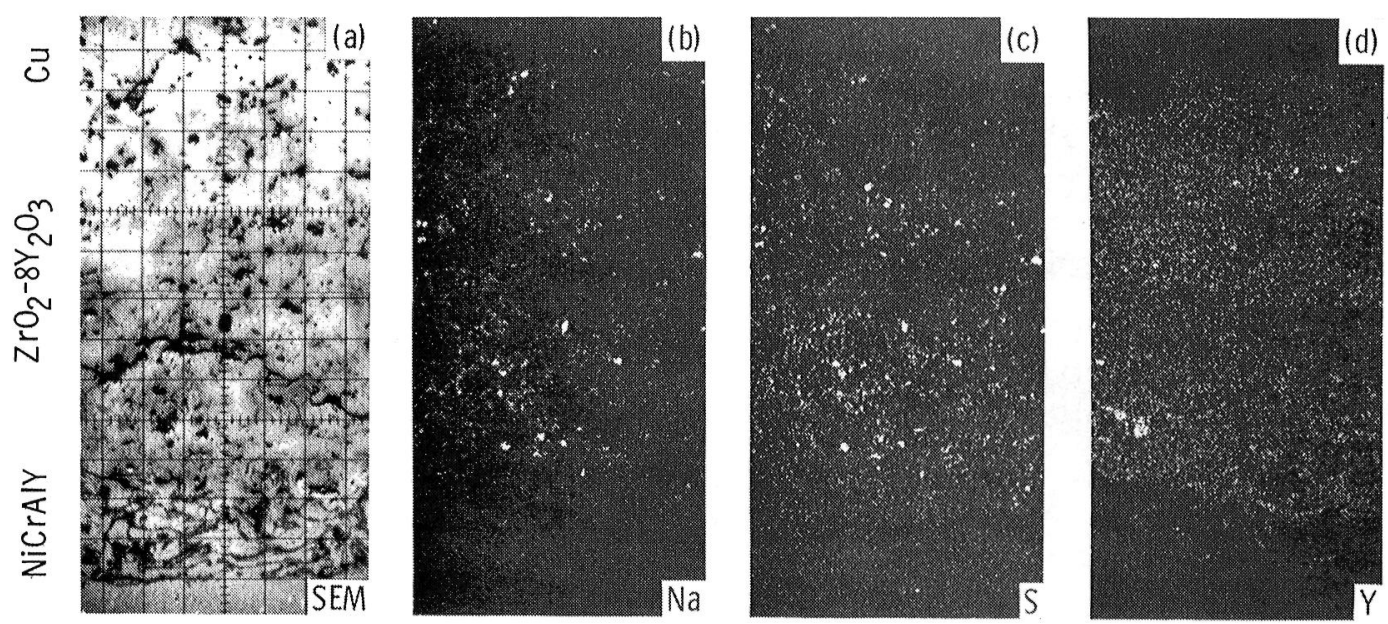

(a) $\mathrm{ZrO}_{2}-8 \mathrm{Y}_{2} \mathrm{O}_{3} / \mathrm{Ni}-16 \mathrm{Cr}-6 \mathrm{AI}-0.31 \mathrm{Y}$ COATING SY STEM AFTER 120 1-hour CYCLES, CROSSSECTION B, LEADING EDGE.

Figure 3. - Electron microprobe maps. 

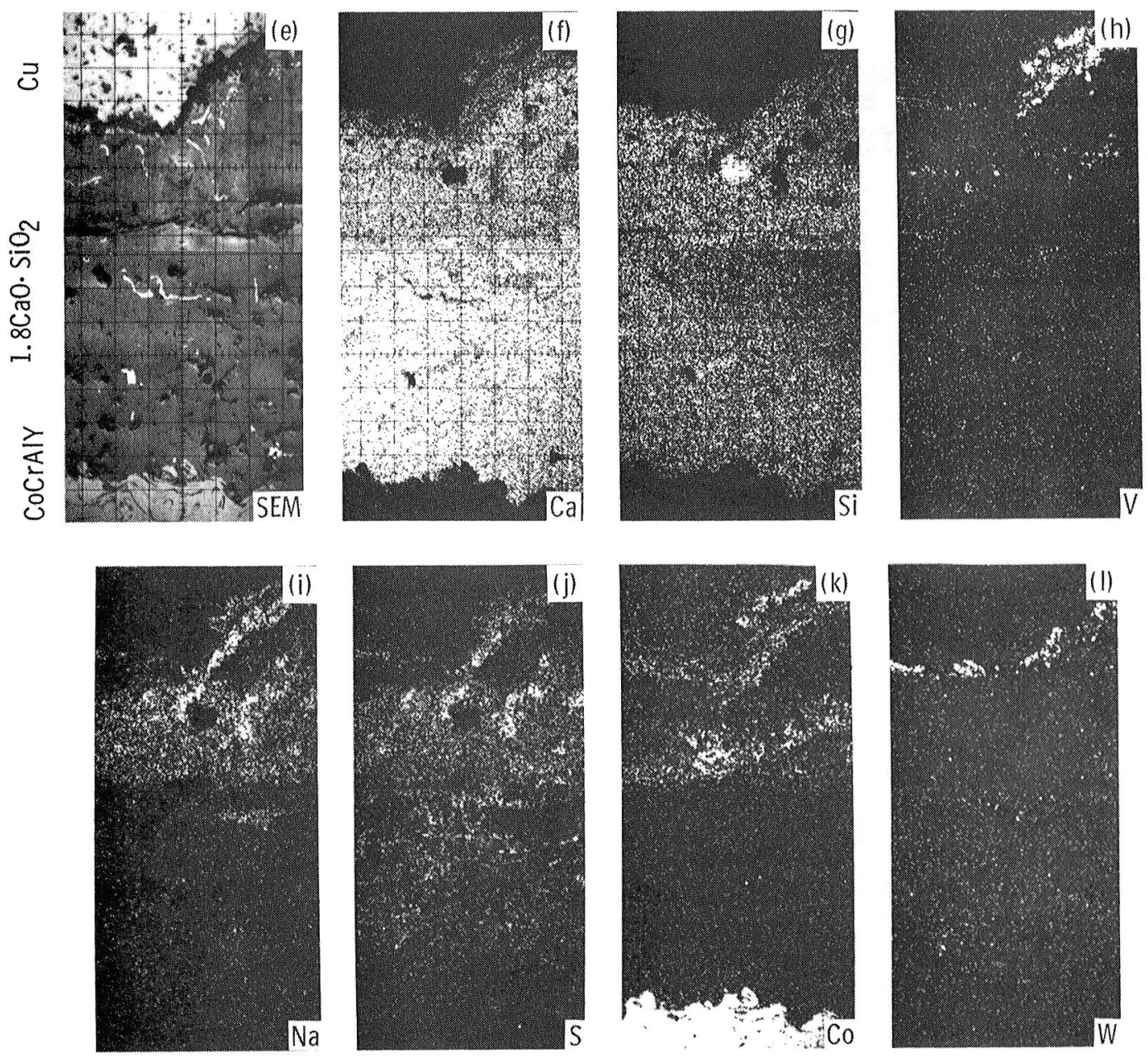

(b) $1.8 \mathrm{CaO} \cdot \mathrm{SiO}_{2} / \mathrm{Co}_{0}-22 \mathrm{Cr}-13 \mathrm{Al}-0.3 Y$ COATING SY STEM AFTER 620 1-hour CYCLES, CROSSSECTION A, LEADING EDGE.

Figure 3. - Concluded. 


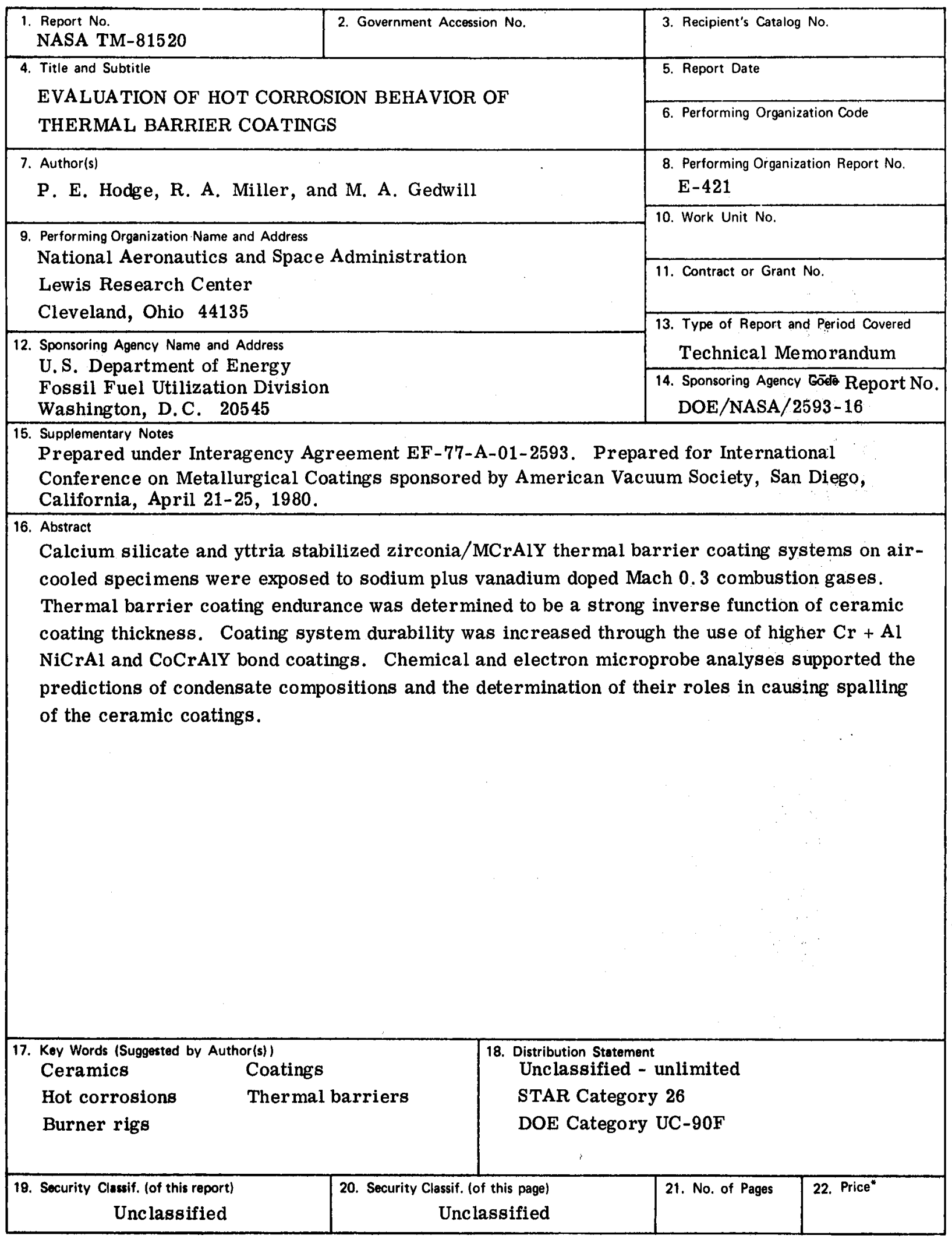

* For sale by the National Technical Information Service, Springfield, Virginia 22161 


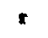


